\title{
Article
}

\section{Science, metaphysics and Calvinism: the God of James Croll}

\author{
Diarmid A. FINNEGAN* (i)
}

\author{
Geography, School of Natural and Built Environment, Queen's University Belfast, Northern Ireland, BT7 1NN. \\ *Corresponding author. Email: d.finnegan@qub.ac.uk
}

\begin{abstract}
Science, for James Croll, began and ended in metaphysics. Metaphysics, in turn, provided proof of a First and Final Cause of all things. This proof rested on two metaphysical principles: that every event must have a cause, and that the determination of a cause is distinct from its production. This argument emerged from his deeply held religious commitments. As a 17-year-old, he converted to a Calvinist and evangelical form of Christianity. After a period of questioning the Calvinist system, he embraced it again through reading the famous treatise on the will by the New England theologian, Jonathan Edwards. This determinedly metaphysical work, which engaged as much with Enlightenment thought as with Calvinism, defended the view that the will was not a self-determining cause of human action. This 'hard case' provided the basis for a larger claim that every act whatever has a cause, and that the production of an act was different from its determination. In part through reading Edwards, Croll remained a devout and convinced 'moderate' Calvinist for the rest of his life. He also developed a deep love of metaphysics and became convinced that without it, everything, including science, remained confused and in darkness. For Croll, even the most basic science could not be properly conducted without prior metaphysical principles. But this was more than just an argument about the philosophical foundations of scientific inquiry. It was also based on Croll's conviction that the cosmos, earth history and life (including his own) was fully determined by a supreme and perfect intellect. This conviction entered into the marrow of Croll's scientific theories and shaped his interpretation of the twists and turns of his own life. In short, to take seriously Croll's own self-understanding, we need to allow him to 'do God'.
\end{abstract}

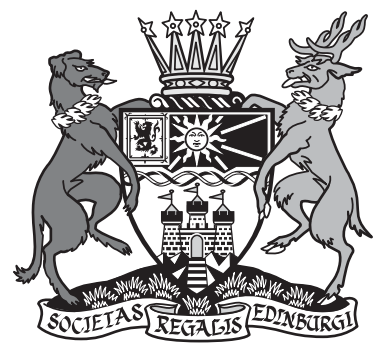

KEY WORDS: causality, Congregationalism, Darwinism, design, determinism, evolution, teleology, theism.

In his short autobiography, completed three years before he died, Croll recounts a curious incident he experienced as a young man that demonstrated to him the 'strange ... ways of providence'. Having not long given up being a joiner on account of an elbow injury, the young Croll was in want of another occupation. The tea trade was suggested to him, so Croll travelled from his home in Wolfhill to Perth to see what might be found in that line. As he approached the town, he observed a man distributing handbills. In a move his older self described as 'absurd and incautious,' he decided that if the advertisement was for a tea shop he would visit it directly. ${ }^{2}$ It proved to be so and Croll took himself to the shop. This chance encounter and apparently rash decision turned out to be highly fortuitous. The tea merchant trained him in the art of shopkeeping and bankrolled the cost of setting up shop in Elgin the following year. It was there that Croll read Jonathan Edwards, the thinker that, perhaps more than any other, influenced the direction and form of Croll's intellectual labour. As he reminisced on these turns of events, Croll surmised that these chance encounters and arbitrary decisions had all been divinely orchestrated.

As his autobiography amply shows, James Croll's life was a religious as much as a scientific one. From the age of 17, Croll took religious questions - more often than not formulated in abstract and metaphysical terms - with a deep and personal seriousness. After some early doubts, he remained a committed Congregationalist and Calvinist to the end of his life. His autobiography indicates that he was a person of strong personal and intensely private piety, a frame of mind and heart that undoubtedly shaped his public persona, career paths and intellectual projects. Croll was convinced that his life was lived under the direction (or, to use his preferred term, determination) of divine providence. As the opening anecdote shows, the many twists and turns of his life's path were thought by Croll to be divinely directed. Croll later applied this traditional Christian conviction to the entire cosmos, to earth history and the history of life. Evolution, with all its contingent and unpredictable trajectories over a vast timescale, was, in Croll's religious conception, as fully determined by the Creator as his own convoluted life.

Croll was raised in a deeply religious home. His family attended a church that was part of the Congregational Union of Scotland, a loosely bound denomination that included upwards of 100 individual churches. It was, as the religious historian Tim Larsen describes it, 'a drop in a Presbyterian ocean,' surrounded by much larger Presbyterian denominations, including the established Church of Scotland. ${ }^{3}$ The Scottish

\footnotetext{
${ }^{1}$ Irons (1896, p. 20).

${ }^{2}$ Irons (1896, p. 69).
}

${ }^{3}$ Larsen (2017, p. 39).

(c) The Author(s) 2021. Published by Cambridge University Press. This is an Open Access article, distributed under the terms of the Creative Commons Attribution licence (http://creativecommons.org/licenses/by/4.0/), which permits unrestricted re-use, distribution, and reproduction in any medium, provided the original work is properly cited. doi:10.1017/S1755691021000190 
Congregational churches were marked by a commitment to the spiritual independence of local congregations, missionary work (at home and further afield) and revivalism. The missionaryexplorer David Livingstone (1831-1873) was arguably the denomination's most famous member.

Perhaps in part because of its marginal status and the emphasis on independency, congregationalism nurtured theological innovation and controversy, something Croll himself fully embraced as a young man. One example of this was his participation in a growing movement within and beyond Congregationalism that questioned the viability of Calvinism as a theological system (upheld, of course, by a dominant Presbyterianism). Croll later embarked on a journey back to Calvinism under the influence of the New England theologian Jonathan Edwards. This moved him in a direction that ran against a growing trend within Scottish Congregationalism through the 19th Century that has been described as a 'revolt from Calvinism' by historians of the denomination. ${ }^{4}$

Wherever Croll sat with respect to wider theological trends within his own church, he nevertheless exhibited in full strength the dissenting attitude that Congregationalism was famous for. Croll demonstrated throughout his life, in philosophy, science and social affairs as much as in religion, strong independence of mind and heart. He was a dissenter in nearly all matters he cared about and was unafraid of controversy and public debate. He doggedly refused to show deference to those regarded as established voices in science, politics or religion. His many disputes with leading scientific figures were conducted with the persistence, passion and polemics reminiscent of the theological battles he had fought in his youth. Raised with a Congregationalist's commitment to the importance of individual conscience and personal conviction, Croll stubbornly resisted arguments given extra credence because advanced by someone with an elevated social position or backed by majority opinion.

Placing Croll within the religious tradition that so shaped him sheds light on how he articulated his scientific and philosophical ideas. But Croll's deeply held theological convictions strongly shaped not just his conduct and attitude. It also entered into the marrow of his scientific and philosophical proposals. Segregating Croll's religious commitments from his science divides what he struggled earnestly to hold together. The rest of this article follows those struggles from Croll's early religious experiences and beliefs through to his final arguments about the truth of theism. Particular attention will be paid to his encounter with the North American philosopher and theologian Jonathan Edwards and to his early efforts to defend a metaphysical proof of God's existence. Although Croll then left philosophical concerns in the background until the very end of his life, I will also indicate some of the ways his commitment to a theistic metaphysics shaped at depth his better-known scientific proposals. This undercurrent resurfaced in Croll's final book on metaphysics in which he argued once again that science as much as life had its beginning and its end in the eternal mind of God.

\section{Conversion and controversies}

In his brief reminiscences written towards the end of his life, Croll offers a compact account of his early religious influences. Although raised a Congregationalist by devout parents, he recalls that he was 'indifferent to divine things' until the age of 17. ${ }^{5}$ It was a book, Thomas Boston's Human Nature in its Fourfold State (1720), that awakened what became an intense and life-changing interest in the Christian religion. Boston's

${ }^{4}$ Larsen (2017, p. 49).

${ }^{5}$ Irons (1896, p. 18). collection of sermons had been a religious bestseller in Scotland since it first appeared. It had entered into the Scottish religious psyche and was revered and reviled in a culture steeped in the kind of Calvinism it so forcibly espoused. Boston (1676-1732), a Scottish Presbyterian minister, had been anxious to lay out the basics of Calvinist or Reformed Christianity in a way accessible to his mostly rural congregation in the small town of Ettrick in the Scottish borders. ${ }^{6}$ He based his sermons on a division of the Christian account of the relationship between God and humans proposed by Augustine of Hippo in the 5th Century and further developed by Reformed theologians in the 16th and 17th Centuries. For these theologians, not least John Calvin, the first human couple were created in a state in which it was possible for them not to sin. When they did in fact disobey their Creator, Adam and Eve and their descendants entered a second state in which they found it impossible to resist sin (they could not not $\sin$ ). The death of Christ provided the means by which humans could enter a redeemed (third) state in which they were able again not to sin. The fourth state was reserved for eternity, a final sinless stage in which fully redeemed humans were, at last, simply unable to sin. Boston's book gave a lively rendition of this classic account of creation, fall, redemption and final salvation. Crucially, his sermons had a strong evangelical tone and sought an urgent response from those that comprehended their message. Paradoxically however, and following Calvin, Boston regarded the human will in its fallen state as in bondage to sin. Only God could set humans free. Boston also subscribed to the idea that only an elect portion of humanity would be saved through God's eternal decree or decision. The fate of the reprobate, or unsaved, were similarly pre-ordained by divine decision. Underlying this notion of 'double predestination' was a conviction that human free decision and God's sovereign election were ultimately compatible (even if that truth terminated for now in mystery). Among other things, then, Calvinist theology was an invitation to intricate metaphysical deliberations about the will, freedom and Divine action.

Croll's 17-year-old self, on reading Boston's sermons, felt strongly the need to be rescued from bondage to sin. He presumably recognised himself in the description of the fallen state of humankind. He hints, however, that it took him some time to apprehend the answer Boston offered to this state of sinfulness. Once understood, however, Croll found himself transformed. In his later recollections, Croll recounts the 'complete peace of mind and true happiness' that he experienced on realising that Christ's 'vicarious death,' was freely given, could be freely received and that 'salvation was entirely of free grace'. ${ }^{7}$ These were two classic marks of a Calvinist account of the meaning and theological import of Christ's crucifixion.

This same account of Christian belief was reinforced through the influence on the young Croll of the evangelical Church of Scotland minister, Andrew Bonar. Based at Collace, a village not far from Croll's home in Wolfhill, Bonar had been involved in the revival of the kind of evangelical Calvinism that Croll had encountered so forcibly in Boston's book. Bonar's own understanding of Presbyterian Christianity had been significantly influenced by Boston's theology and his preaching replicated the same passionate style of evangelical address that Boston had cultivated more than a century previously. In a passing remark made in 1849 to his friend and theological sparring partner James Morison, Croll notes that it had been Bonar who had 'brought $[\mathrm{him}]$ to the truth' ${ }^{8}$ Bonar's ministry, with its

\footnotetext{
${ }^{6}$ For the origins, content and influence of Boston's book, see Ryken (1999).

${ }^{7}$ Irons (1896, p. 17)

${ }^{8}$ Irons (1896, p. 74).
} 
emphasis on an explicit, personal and deeply felt acceptance of the offer of salvation, had helped the young Croll to identify himself as one who had responded wholeheartedly to Divine grace. It was, as Croll later recorded, a religious self-understanding that remained with him, and remained dear to him, for the rest of his life.

Bonar, like Boston, was a Calvinist of a particular stripe. He emphasised the need for a public as well as personal response to the Christian message of salvation. The emphasis on a clear conversion from a state of sin to a state of forgoing wrong and relying on divine aid was critical. Yet Bonar, in keeping with Boston's views, also emphasised divine initiative and human passivity, refusing any sense that human decision contributed to a person's salvation. ${ }^{9}$ Croll, it seemed, quickly grasped the attendant perplexities of the theological system that structured and informed Boston's and Bonar's account of Christian salvation. In what sense could anyone be held accountable for sins that they apparently could not avoid committing? If salvation was God's initiative alone, with no contribution being made by the recipient, why save only some rather than all? These questions had already been raised and addressed by Boston but not, it seems, to the satisfaction of a young millwright and budding metaphysician reading them just over one hundred years after they had first been printed.

In 1843, Croll had returned home to Perth after an unhappy three years carrying out millwork in Banchory. His unhappiness, on his account, was exacerbated by the lack of contact with likeminded Christians. His thoughts, however, continued to be engaged with theological concerns, not least with an issue that had become a matter of public and formal controversy among Scotland's third largest Presbyterian denomination, the United Secession Church (USC). The Rev James Morison, one of the USC's ministers, had increasingly turned against Calvinism and, after his suspension from the Presbyterian denomination, set up his own independent congregation in Kilmarnock. ${ }^{10}$ In May 1843, he and a number of others similarly removed from their respective denominations for upholding anti-Calvinist positions, established the Evangelical Union and set about increasing the number of churches that subscribed to Morison's theology. In that year, Croll had become aware of Morison's polemical pamphlets outlining his opposition to central tenets of Calvinism. This persuaded Croll, for a period, that the account of salvation he had encountered in Boston and from Bonar was not defensible. Though as a millwright he helped build Bonar's new church in Kinrossie in the spring of 1844, erected in the wake of the seismic and separate disruption of the Church of Scotland the previous year, he was already moving away from evangelical Calvinism. When Croll relocated to Paisley in 1844 in search of work, he joined with Morisonians intent on establishing an Evangelical Union church in the town. Croll avidly participated in the earnest and intense discussions provoked by the theological controversies surrounding Morison and listened with admiration to sermons by two of Morison's leading advocates, the Rev William Landels and the Rev Alexander M. Wilson. Before he left Paisley in 1846, he had been appointed a deacon in the newly formed Evangelical Union church which rented the large Gothick building of the Laigh Kirk on New Street for their meetings.

The question of free will lay at the heart of the controversy surrounding Morison's break with Calvinism. Those adhering to the Westminster Confession of Faith (the 'subordinate standards' or core doctrinal commitments of Presbyterian churches) and to

\footnotetext{
${ }^{9}$ On Bonar, see Gribben (2004).

${ }^{10}$ For more on Morison and the Evangelical Union, see McKimmon (2019).
}

Calvin's religious doctrines, insisted that humans, in their fallen condition and under their own strength, were unable to do anything that would move them towards salvation or conversion. Their will was entirely enslaved to (or determined by) sin and they were subject to God's judgement. It was this doctrine, and the view of human freedom (or lack of freedom) that went with it, that Morison and his followers increasingly doubted. Croll was among those who felt strongly the draw of Morison's stinging critique of Calvinism. In this he followed others within Scottish Congregationalism, including, for example, the author George Macdonald, who also found the thought that Christ had died for all that all may freely respond more compelling than the Calvinist alternative.

As already mentioned, in 1846, Croll left Paisley and the Morisonians to pursue a new career as a tea merchant. This took him the following year to Elgin, his mother's hometown. A little over 12 months later, in September 1848, he married Isabella Macdonald in Forres Congregational Church. This major life event is noted but not much reflected upon by Croll or by his memorialists. Instead, what looms large in Croll's recollections of this period is his close study of Jonathan Edwards' two volume treatise, Freedom of the Will (1754). It was this book more than any other that persuaded Croll that James Morison was in fact wrong and that the central tenets of Calvinism could be defended against its many modern detractors.

\section{Tea with Jonathan Edwards}

Croll's reading of the classic work defending and revising Calvinism by the New England theologian Jonathan Edwards (17031758) took place in a small tea shop in Elgin over a period of about a year and half. It was a book that addressed at great length, and in forensic detail, the objections to Calvinism that had caused Croll to join the Morisonians some years previously. Edwards' aim was to show that the account of the will presumed by those who thought that humans could freely embrace or refuse salvation was incoherent and untenable. ${ }^{11}$ His counterargument was that all events, including human choices, were caused by previous events and followed by necessity from them. Cast in theological terms, everything was ordered by a 'universal, determining providence,' including moral conduct and human response to Divine grace. ${ }^{12}$ However, the idea that humans could neither avoid sinning nor escape from that condition was, Edwards insisted, compatible with culpability, responsibility and consequent divine judgement. Humans, Edwards argued, had a natural ability to act rightly but a moral inability to do so. The fact that their actions followed by moral necessity did not excuse them. Beyond these distinctions, the fundamental metaphysical point of Edwards' treatise, which Croll found unassailable, was that every event has a cause, including an act of the will.

In between serving customers, Croll read Edwards' Freedom of the Will several times, slowly. Indeed, his study of Edwards' argument sentence by sentence, and then over again, led him to the conclusion that 'it is probable that no-one has ever devoted so much time to the study of the book as I have done'. ${ }^{13}$ After this laborious engagement with Edwards, Croll became a lifelong convert to his views. This did not prevent him from engaging with Edwards' sternest critics. After reading Freedom of the Will, Croll spent part of his small salary on probably the bestknown rebuttal of Edwards' argument at the time, written by the American philosopher and Congregationalist Henry Philip

\footnotetext{
${ }^{11}$ For an authoritative overview, see Guelzo (2005).

${ }^{12}$ Edwards (1957 [1754], p. 431).

${ }^{13}$ Irons (1896, p. 22).
} 
Tappan. Croll tells us that after an equally careful study of Tappan, he remained firmly convinced that Edwards was correct.

In accepting Edwards' position, Croll was embracing a theological account that had exercised huge influence on both sides of the Atlantic since it first appeared. That influence was not all in one direction. It led some to move away from a traditional Calvinist outlook and led others, like Croll, to return to a more philosophical version founded on engagement with Enlightenment thought as well as on Calvin's theological principles and dogmatic commitments. Although fundamentally concerned with a matter of theological importance, Edwards had adopted a philosophical approach that was, in his time and since, unusual among those defending a Calvinist view. Edwards engaged with leading Enlightenment thinkers and used philosophical arguments to ground and defend theological claims. In this, as in so much else, Croll was to follow Edwards. Once Croll managed to put his own theological and metaphysical views on paper, he did so in a way that interacted in full with early modern, enlightenment and contemporary philosophical thought.

In Britain, Edwards' treatise on the will had a mixed reception, but was widely read in the first half of the 19th Century in Calvinist circles. In Scotland, it had been vigorously promoted by the Rev Thomas Chalmers and other leading Presbyterian figures. It had wide currency, too, among Congregationalist theologians. ${ }^{14}$ But it also had its severe critics and Croll's lifelong commitment to Edwards' metaphysics and theology put him at odds with a widespread rejection of Edwards' philosophical theology by leading Victorian philosophers and intellectuals outside of Calvinist circles. ${ }^{15}$

Croll, however, was not particularly concerned about assessments of Edwards among a cultured and educated elite. He apparently cared more about the opposition of his friends in Paisley and their leader, the Rev James Morison. After reading Edwards and being 'perfectly astonished' by it he began a correspondence with Morison that flowered into a lifelong friendship that endured despite their growing theological and philosophical divergences. In a revealing letter to Morison written on 24 November 1849, Croll explains how Edwards had persuaded him that 'Calvinism was a subject that was not so easily got rid of'. At that stage, Croll was still declaring that the 'doctrine of necessity was hidden in mist and metaphysics' and that he was 'perfectly satisfied that liberty was right'. ${ }^{16}$ Further reading of Edwards, and of a range of other thinkers on questions of freedom, human agency and divine action, convinced Croll that Edwards had the best of the argument.

Croll's growing commitment to Edwards' views took place even as he faced constant upheaval in terms of his own occupation. His work in Elgin as a grocer selling tea failed, forcing a move back to Perth. This was followed by a failed attempt to run a Temperance Hotel with Isabella at Blairgowrie. Croll then found (to him miserable) work as an insurance salesman, a job that took him to Glasgow, Dundee, Edinburgh, Leicester and Paisley all in the space of four years. Somehow during that period, he found time to further pursue philosophy and theology.

During his short stay in Glasgow in 1854, he continued his reading in metaphysics, theology and science, and participated in regular discussions on these issues with a small group of like-minded 'students' in an old bookshop. He also ventured thoughts on both theological and scientific topics in two pamphlets published in Glasgow at this time. One, which he signed as by a 'moderate Calvinist', tackled predestination and mounted a defence of Jonathan Edwards. ${ }^{17}$ The other dealt with the relations between creation, geology and astronomy. ${ }^{18}$ Croll was also reading, with admiration, works by the American moral philosopher, Laurens Perseus Hickok (1798-1888), then Professor of Mental and Moral Science at Union College, New York. In 1855, while stationed in Edinburgh, he also began to read Immanuel Kant. Both Hickok and, even more, Kant shaped Croll's thoughts on metaphysical concerns, not least those that would appear late in 1857 in his first book, The Philosophy of Theism.

The peripatetic Croll moved on from Glasgow, working as an insurance agent in Dundee, Edinburgh, Leicester and Paisley. About mid-way through 1857 he quit the occupation, with some relief, and resided again in Glasgow where his wife was convalescing from a debilitating illness. Without work, he used the time to write, in some haste, his first book. It was published anonymously late in 1857 with the title The Philosophy of Theism: An Inquiry into the Dependence of Theism on Metaphysics and the only possible way of arriving at a proof of the Existence of God. It was the culmination of years of reading about and discussing theology and metaphysics, not least the question of divine action and freedom of the will.

\section{Metaphysical designs}

There are several features of The Philosophy of Theism that are worth highlighting to better understand Croll's maturing religious and metaphysical thought, and his attitude towards science. The first is his insistence that facts qua facts have no explanatory force. It is only when certain a priori principles are brought into play that the quest for scientific explanation can begin in earnest. These principles were not, in Croll's view, discovered through inductive enquiry but arrived at when such enquiry was combined with metaphysical reflection. At the same time, it was not possible to construct an argument for the existence of God without an appeal to sensible facts. One upshot of this was that for Croll arguments for the existence of God based only on observed facts, or on purely a priori principles inevitably failed.

To illustrate the failure of the former 'facts-only' approach, Croll pointed to the 'Development theory'. ${ }^{19}$ This theory of evolution was regarded by some as providing a refutation of the commonplace argument that appealed to the specific functions of living organisms or their organs to argue for a Designer. Croll, though he thought the development theory as it was then formulated was false, agreed. For Croll, the atheist was within their epistemic rights to deny that an intelligent designer was the only possible explanation for the existence of organs with specific functions. Here he followed Kant, and before him David Hume, in denying the validity of the design argument as conventionally formulated. Such design arguments were a form of a posteriori reasoning which, in Croll's judgement, could not prove God's existence. As a result, Croll, while admiring the efforts of his fellow countryman Hugh Miller to rebut the development theory promoted in the anonymously authored Vestiges of the Natural History of Creation (1844), dismissed them as ultimately futile. Miller, like so many authors writing in the broad tradition of natural theology, failed to defend the metaphysical principles necessary for creating a robust case for the existence of God. No assistance in that task could come from the 'geologist, natural philosopher or empirical psychologist' without the essential aid of metaphysics. ${ }^{20}$

\footnotetext{
${ }^{14}$ See Bebbington (2017)

${ }^{15}$ McClymond (2012).

${ }^{16}$ Irons (1896, p. 74).
} 
A second key feature of Croll's book was his defence of the necessity of metaphysics against some of the leading thinkers of his age. Croll believed that metaphysical thought was at a low ebb. It was either rejected or ignored. As a consequence, he spent the second of three sections in his book defending the necessity and inescapable reality of metaphysics. The poor condition of metaphysical thinking was due not to its suspect epistemic status but rather to its being both the oldest form of science and the 'science latest in arriving at perfection'. ${ }^{21}$ It could only be worked out fully once physics, chemistry, geology, biology and psychology had come to maturation. These sciences, as for all systems of knowledge, began and terminated in metaphysics, which Croll defined as the subject that addresses questions about the nature, cause and end of all things. It followed from this that the natural sciences and mathematics, though initially prompted by metaphysical questions, should be studied before any full answers to those questions could be given. Croll's own intellectual biography, which started and finished with metaphysical contemplation in many ways embodied this chronology and this 'science-engaged' metaphysics.

A third component of Croll's book was his insistent metaphysical argument or 'proof' for the existence of God. Croll's emphatic tone on this front was noticed by at least one reviewer, who described the tenor of Croll's arguments as, on occasion, 'autocratic'. ${ }^{22}$ Croll was certainly bold enough to pointedly contradict the views of major philosophical thinkers and metaphysicians including Immanuel Kant, the British metaphysician Samuel Clarke and the Cambridge Platonist Ralph Cudworth. Clarke, for example, is said to have 'done much damage to theism' in arguing from the reality of motion to a creator. ${ }^{23}$ This, Croll believed, was fundamentally mistaken as it ignored the difference between what might be termed 'mere motion' and the determination of motion.

Croll certainly stated his metaphysical argument for God's existence in the strongest terms. It was necessary, he asserted, to properly describe and account for the reality of molecules in motion that moved towards a determinate end. His exemplar was the living organism, but his argument was founded on a 'necessary and universal' principle he had discovered in Jonathan Edwards' Freedom of the Will, namely that 'every event must have a cause'. After doggedly defending this at some length, not least in the face of arguments to the contrary made by John Stuart Mill, Croll concluded with his 'proof for the being of God from organism'. Here his distinction between an act and the determination of an act proved critical. As noted, this distinction borrowed directly from Edwards, who used it to argue that an act of the will was not self-determined and that there was a difference between the production and determination of a volitional act. If the will might be said to produce an act it was a prior state of the intellect or mind that determined it. Croll widened the application of that distinction and argued that something like an eye required both the production of the motion and the determination of the direction of the molecules that composed it. It was the determination of the coordinated arrangement of an eye's molecular parts that presupposed, Croll argued, intelligence, will and desire, or a 'personality' which was God.

The family resemblance between this proposal and Thomas Aquinas's 'fifth way' argument from final causes helps to further illuminate the argument Croll was attempting to make. Croll's (and Aquinas's) teleological argument for the existence of a divine intelligence differed from the generally better-known

\footnotetext{
${ }^{21}$ Anon [Croll] (1857, p. 43).

${ }^{22}$ Morison (1858, p. 138).

${ }^{23}$ Anon [Croll] (1857, p. 99).
}

design argument made by William Paley in his Natural Theology (1802). Both Aquinas and Croll, purportedly unlike Paley, presuppose that a stringent metaphysical defence is necessary before making the move from order or teleology in nature to a supreme intelligence. ${ }^{24}$ Whatever the validity of Croll's metaphysical distinction between movement and its determination or direction (and there is little evidence he persuaded many of his contemporaries), he insisted that this had to be demonstrated a priori before making the move from specific examples of ordered causation to a divine intelligent agent. He would return to this point again later in his life, and then with the reality of evolution much more in mind.

With only 500 copies printed, The Philosophy of Theism received only limited review attention. One extended notice appearing in the Greenock Telegraph defended the inductive design argument of Paley, and more generally suggested that Croll had allowed the 'wheels' of his argument to 'run too fast for the body of the carriage. ${ }^{, 25}$ Another fuller review, written by Croll's friend and critic, the Rev James Morison, was published in the Evangelical Repository. ${ }^{26}$ Morison's sustained critique left Croll's book looking like a confused mess marked on too many occasions by a fruitless 'logomachy'. This demolition appears to have been largely motivated by Morison's bitter disagreement with religious rivals who used Jonathan Edwards to defend core components of Calvinism. Morison could not be expected to do anything other than strike hard against a book that rested so centrally on the plausibility of Edwards' metaphysical defence of Divine determinism.

Beyond the merits or otherwise of Croll's first book, it provides important background to his later career and further insight into his views of science, theology and metaphysics. Philosophy of Theism shows us an author deeply committed to defending the truth of Christian theism, and in a way that differs markedly from many (but by no means all) of his co-religionists who shared the same aim. ${ }^{27}$ His desire to discern and defend fundamental principles is something that can be seen later in his scientific theorising. And his turn to metaphysics also allowed him to embrace scientific findings without reservation in way that set him apart from others, at least in this earlier period, who shared his theological commitments. Croll's awareness of, and response to, the fragility of a standard account of the design argument meant that theories of evolution did not carry the same threat for him. Such theories did not touch, in Croll's mind, the fundamental principle on which his own proof of God's existence rested.

All this goes some way to explain how a devout Christian like Croll could embrace the findings of science, and engage with scientific developments, without any indication they unsettled his own religious convictions. The age of the earth, evolution and other headline 'threats' to traditional Christian beliefs appear to have rolled off Croll's metaphysical back. He felt free to immerse himself in scientific study without being unsettled by what he found. As we know, this is indeed what he did. Two years after he had communicated to the world his proof of

\footnotetext{
${ }^{24}$ The literature on Aquinas is extensive and contested, but for two recent accounts that distinguish between the fifth way and William Paley's design argument, see Feser (2013) and Newton (2014).

${ }^{25}$ Anon $(1857$, p. 1$)$

${ }^{26}$ Morison (1858).

${ }^{27}$ There is not space here to compare in detail the defence made by other Scottish Calvinists of design arguments in the face of the challenge presented by evolution in the period before the publication of Darwin's On the Origin of Species (1859). For the wider, sometimes panicked and mostly negative, religious reactions to Vestiges of the Natural History of Creation in Scotland (especially Edinburgh) and across Britain and Ireland, see Secord (2000).
} 
God's existence, he had the unexpected opportunity of turning from metaphysics to a long-term study of physical science.

Croll's metaphysical argument, as well as enabling the enthusiastic pursuit of science without precipitating a crisis of faith, set the foundations for his approach to scientific inquiry. Although he sometimes described his scientific studies as a regrettable turn away from metaphysics, his 'first love,' he did not finally separate the two intellectual pursuits. ${ }^{28}$ As we have seen, metaphysics for Croll would only be perfected once it could take full account of other sciences in their most mature form. On Croll's telling, metaphysics emerged from a synthesis of a priori principles and sense experience ordered by scientific reasoning. While Croll himself made a pragmatic distinction between scientific and metaphysical work (which he described as occupying different 'regions of inquiry'), his inclination towards metaphysics continued to exercise an influence even as he took up scientific investigations in earnest in the winter of $1859 .{ }^{29}$

\section{A scientific interlude}

After the publication of his book, Croll took up a position at the Commonwealth offices in Maxwell Street, Glasgow. The weekly temperance newspaper provided work that did not risk further physical injury. Then, in the winter of 1859 , he was appointed janitor at the Anderson's College Museum, a post he held for the next eight years. Here he began his scientific studies in earnest, beginning with work on the physics of heat, electricity and magnetism before shifting attention to astronomical causes of ice ages. His first publication on the latter appeared in the Philosophical Magazine in 1864 and attracted a much greater amount of attention and from much more prominent thinkers than anything he had written on metaphysics. He started, of course, where he believed one should start if working through the sciences to get (back) to metaphysics, namely with the most fundamental or basic sciences. The journey back would prove to be a long one for Croll. Even so, he did not forget that all physics begins as well as ends in metaphysics.

As Croll made the move to scientific study, his steady commitment to religious observance as well as metaphysical argument continued. During this period in Glasgow, Croll, his wife and his brother attended Elgin Place Congregational Church. Though there is no record of Croll's own thoughts on the congregation or its charismatic minister, the Rev Henry Batchelor, it is likely that he faithfully attended the weekly services until his move to Edinburgh in 1867. Batchelor's commitment to independency, the importance of individual conscience, his distaste of enforced subscription to creeds and confessions and his vision of an 'evangelical catholicity' that allowed room for doctrinal disagreement will have resonated with Croll's own approach to managing religious differences. Batchelor was also well known for sermons 'illuminated by ... a passion for the beauties of nature in earth and sea and sky,' a practice that Croll, who shared this enchantment with the natural world, may well have warmly appreciated. ${ }^{30}$ This declared love of creation's beauty, echoed by his minister's sermons, was an aspect of Croll's religious sensibility that is worth placing alongside the more austere and rarefied metaphysical correlates of his faith. ${ }^{31}$

As others have shown in detail, over the next three decades Croll spent most of his time working on scientific topics. His move to the Geological Survey of Scotland's offices in Edinburgh in 1867 , made possible by his growing scientific reputation, kept

\footnotetext{
${ }^{28}$ Irons (1896, p. 472).

${ }^{29}$ Irons (1896, p. 32).

${ }^{30}$ Caldwell (1904).

${ }^{31}$ For Croll's love of nature's beauty, see Irons (1896, p. 36). See also Croll (1890, pp. 164-65).
}

him on a scientific more than metaphysical course. For a start, science paid better than metaphysics and brought more reputational rewards. Even so, as Croll made his scientific ideas felt, particularly in British and American circles, his metaphysical mind did not remain inactive. As argued elsewhere, the nature of his contributions to debates about the physical causes of ice ages and to ocean currents in particular were shaped in quite fundamental ways by his theistic metaphysics. ${ }^{32}$ Croll's firm conviction that good science was about finding and formulating sound physical principles that provided explanations for observed facts was born of his belief that the ordered cosmos was a result of the continuous operation of the divine intellect and will (in that logical order). Human minds, insofar as they could grasp principles of order in nature, were able to discern, even if dimly, the mind of God. It is only by understanding this basic conviction that the form and substance of Croll's sometimes fierce debates with other scientific thinkers can be fully accounted for.

This was perhaps most obviously the case in his long-running dispute with William Carpenter over the causes of ocean currents in the early 1870s. Carpenter held a diametrically opposed account of divine action to Croll and, as a consequence, also held to a contrasting philosophy of science. Carpenter did not believe that nature could be studied as a repository of divine ideas or thoughts but rather as a consequence of God's freely willed actions, the reasons for which remained finally inscrutable. A shorthand way of summarising this is to suggest that Carpenter held to a voluntarist view of God that stressed will rather than intellect as the ultimate basis for divine acts. It led logically to an approach to scientific investigation that gave inductive inquiry priority in adjudicating competing explanations, even if they went beyond known physical principles. We should not presume to know God's choice of natural means and methods. The only thing to do was to look and see. Nature's ways were ultimately as inscrutable as its Author's.

Croll disagreed. Croll's metaphysics informed his philosophy of science, which, in turn, shaped his research practices and theoretical constructs. When the natural philosopher studied nature, mind met mind and divine reasoning was apprehended by a human intellect governed by identical processes of thought. Nature had an intelligible structure discoverable through rational principles already implanted in nature and, at least in nascent form, in the human mind. In light of this, it is not surprising that he settled on an astronomical cause to explain patterns of hemispherical warming and cooling. It was characteristic of Croll to use an established physical principle and cause to construct an explanation for data derived from empirical study, whether of ocean currents or the earth's climate. This emerged from his view that nature was fundamentally orderly, an expression of a supreme intellect, and that physical principles themselves pushed the dedicated inquirer towards higher order metaphysical truths that yet more clearly displayed fundamental patterns of divine reason. Croll's conviction that divine reason, or wisdom, was prior to divine 'motion' or willing, was more akin to an 'intellectualist' understanding of God's being.

The deep metaphysical structure of Croll's scientific research and theorising was just one way that his theological convictions informed proposals that otherwise appeared to be unconnected to his religious commitments. Though he published little on metaphysics or theology during the long period in which he dedicated himself to science, he did not cease entirely to communicate his philosophical views. A couple of these are worth noting here. First, quite unexpectedly, in the middle of a scientific article about the age of the Earth published not long after his move to Edinburgh, he provided a pointed precis of his view of

\footnotetext{
${ }^{32}$ Finnegan (2012).
} 
divine action. Then, four years later, he wrote an article-length critique of Thomas Henry Huxley's argument about 'molecular teleology', which had suggested that the whole cosmos was a result of the law-governed interaction of forces inherent in the first primitive molecules. Croll argued that this form of determinism (and, to him, materialism) missed a crucial and necessary ingredient, namely the directing of those forces by a divine intellect acting not now and again in time but continuously from eternity. The unfolding of the universe, including, as Croll was now happy to admit, the evolution of life, was providentially governed and was not the mindless outworking of primitive and wholly material processes.

At around the time Croll wrote this piece, he was confessing privately to religious friends that he was finding science, and scientific workers, increasingly indifferent or hostile to theism. In 1871, in a candid and revealing letter to the Rev Osmond Fisher, the Anglican cleric and geophysicist, Croll complained that he had no time for the idea, promoted in his view by the British Association for the Advancement of Science, that 'science is the all-important thing'. There are, he declared, 'more noble and ennobling studies than science'. ${ }^{33}$ Five years later he communicated similar sentiments in a letter to his old friend and critic, James Morison, noting that he found a 'cold and materialistic atmosphere around scientific men'. It was for that reason that he 'mix[ed] but little with them'. ${ }^{34}$

Despite his own disaffection with the world of science, Croll nevertheless continued to concentrate on scientific studies, to the neglect of a sustained and serious engagement with metaphysics. This was often a matter of necessity or honour. Responding to critics and defending his theories meant more articles, and more time spent preparing them. It remained the case that books on science sold better than books on abstract metaphysics and his forced early retirement from the Geological Survey had not helped his bank balance. Between his now best-known work, Climate and Time, which first appeared in 1875 and the final year of his life, Croll read, thought and wrote mainly about science.

The only exception to this long hiatus was an article published in 1879 in the British Quarterly Review. In this piece, Croll dealt more directly and deliberately with evolution, repeating at greater length his argument with Huxley. The main title, 'Evolution by force impossible,' made Croll's main point with characteristic directness. He now took the evolution of life as a given but argued that it could not be understood or explained simply by reference to the mindless play of molecular motion. Natural selection, which Croll extolled as Charles Darwin's 'great principle,' was only effective because of the forces operating in nature were 'adjusted' or directed towards particular ends. This was a necessary condition for natural selection to get off the ground. His article did, on this occasion, attract some positive responses, even if his main metaphysical point did not persuade. Correspondence with Alfred Russel Wallace, George Romanes and the Aristotelian philosopher Shadworth Hodgson all found merit in Croll's arguments, despite their general scepticism towards Christian theism.

Croll's scientific writing and thought between 1857 and 1889 was never, in his mind, irrelevant to his larger metaphysical project and ambitions. In practical terms, however, it did prevent him, much to his regret, from publishing more on metaphysics. It was only in the final years of his life, when his circumstances had improved somewhat, that Croll was able to set down his thoughts in a book published just weeks before his death.

\section{Life's final end}

In the summer of 1886 , Croll moved back to Perth with his wife after an easing of financial struggles. In making the move, Croll returned close to his birthplace and to his religious roots. He and his wife attended the Congregational Church that Croll had been baptised in. David Caird, the minister there during the final two years of Croll's life, recalled Croll 'one forenoon' visiting the 'old [Church] building in Mill Street' and sitting where he and his father used to sit. Caird interpreted this as a poignant testimony to the meaning Croll continued to invest in the religious beliefs that had so shaped his life and thought.

It was also in Perth that Croll finally circled back to his metaphysical studies, writing a book published under the title The Philosophical Basis of Evolution. Like his first book on metaphysics, Croll found his time limited, on this occasion on account of failing health. The book repeated, in fuller but still in somewhat fragmented terms, the same arguments that he had presented over 30 years previously. Like his first book, Croll interacted with contemporary philosophers. He also, more than in his first, drew on and engaged with science, not least theories of evolution. The fundamental principle on which he erected his arguments remained the one he had lifted from Jonathan Edwards - that 'every event must have a cause'. ${ }^{35}$ And he continued to press hard the distinction between the production and determination of force, using this to argue from molecular teleology to a divine superintending intelligence.

Croll's last efforts to present his metaphysical views were of a piece with his longstanding religious convictions. One passage in particular demonstrates this. In a section arguing that 'force cannot determine force' Croll turns to a debate that had erupted at around the same time he was working in earnest on the causes of ice ages. The 'prayer-gauge debate' of the early 1870s had raged over a number of years, thanks, not least, to the efforts the Irish physicist John Tyndall. ${ }^{36}$ Tyndall's argument was that the law of the conservation of energy meant that prayer could not be considered physically efficacious. The physical universe was a causally closed system, as the science of energy had demonstrated. Energy was neither created nor destroyed. To pray for the weather, or for the sick, or for the alleviation of a plague, was to ask the impossible. It was akin to praying that a stream would flow uphill, an absurd thought that no sane person would consider acting upon.

Quite clearly, this argument targeted a core Christian conviction that God interacted directly with nature in miraculous or immediate ways that changed its course according to his purposes and in response to the petitions of human intercessors. It was natural, then, for Croll to critique Tyndall's position. But this well-known dispute was also useful for illustrating his own metaphysical argument for God's existence, and for God's continual action in the world. The lynchpin of Croll's counterproposal was that there was no requirement for any input of energy or force to determine (as opposed to produce) the direction a force took. Croll could therefore argue that a change in the weather as a consequence of prayer was quite conceivable (and believable) without contravening the causal closure principle or the laws of conservation. As he put it, 'deflection to any amount can be produced without work'. ${ }^{37}$ This, Croll pointed out, was as true of planetary orbits as it was of meteorological forces. It is worth noting, that without stating as much, Croll was effectively saying that the ice ages as much as the weather had been determined by divine intelligence. In other

\footnotetext{
${ }^{33}$ Irons (1896, p. 262)

${ }^{34}$ Irons (1896, p. 312 )
} 
words, that God's 'perfect intelligence' operated at all temporal and spatial scales. ${ }^{38}$

Croll further substantiated his argument by turning again to human volition. Here he repeated his insistence that the will cannot determine choice. In other words, will by itself was not selfdetermining. Instead, consciousness of a particular internal state' guided, or determined, the will to act in a particular way. In a detailed appendix he pressed his argument against 'freewillers' while denying that his necessitarianism removed moral responsibility from human creatures. ${ }^{39}$ Having made this point to his own satisfaction, Croll then turned to deal with organic evolution, which was often used, as he pointed out, to dismiss any kind of teleological or design argument. Dealing first with Herbert Spencer and then with Darwin, Croll acknowledged that some versions of the design argument were vulnerable in the face of the reality of evolution (which Croll accepted). In the end, however, Croll worked to persuade his readers that evolution 'leaves unshaken the foundations of the great principle [of teleology], or rather so widens and deepens those foundations, that we are enabled to erect upon them a far nobler structure than our fathers [sic] could conceive. ${ }^{40}$

His argument began and ended with molecular teleology, a sub-stratum of existence that was, Croll argued, entirely independent of evolutionary forces (particularly natural selection). The arrangement of molecules into any living form whatever could not be explained, Croll argued, simply by reference to matter in motion or the reality and persistence of force as such. The organisation of molecules necessary for a leaf or an eye - each of which had a clear function or goal - pointed to the existence of what Croll termed an 'objective idea' or plan. Though acknowledging that the eye or the leaf had emerged gradually though a process of evolution, he denied that Spencer's arguments about the persistence of force or the theory of natural selection provided any kind of causal explanation. Force alone could not produce organisation and natural selection could only 'get off the ground' because of the prior determination of molecular arrangements. Like a number of contemporary critics of Darwin at the time, Croll argued that natural selection did not name an agent or cause (and in that sense was a misleading concept) but merely described differential survival rates. ${ }^{41}$ The cause of the variations or traits that gave some slight advantage and thus increased the chances of survival remained untouched. Croll was thus convinced, and tried to convince his readers, that there remained ample scope to look elsewhere for the cause of organs and organisms that displayed what to him were clearly goal-directed behaviours.

Croll's metaphysical arguments were undoubtedly motivated, at least in part, by his religious convictions. It remains open for discussion as to whether they speak to current debates in metaphysics and the philosophy of mind and of religion. To give just one possible point of contact, current debates within the philosophy of mind about the reality or otherwise mental causes remain not too distant from Croll's wider arguments about the operations of a Divine mind. A certain resemblance can be seen between Croll's argument that the determination of the will or of any force whatsoever does not require expenditure of energy and recent critiques of arguments that appeal to causal closure based on conservation laws to deny the reality of mental causes. $^{42}$

\footnotetext{
${ }^{38}$ Croll (1890, p. 166).

${ }^{39}$ Croll (1890, p. 171-90)

${ }^{40}$ Croll (1890, pp. 166-67).

${ }^{41}$ For other religious thinkers that attacked the idea that natural selection was a cause or agent, see Livingstone (2014).

${ }^{42}$ Gibbs (2010).
}

Whatever view we might arrive at about the ongoing relevance or plausibility not just of Croll's scientific work but also his metaphysics, it is hard not to conclude that ignoring or denying the centrality of Croll's religious and metaphysical convictions would do violence to his own self-understanding. For all the pride Croll apparently felt in his scientific accomplishments and the recognition of them through awards and fellowships, it seems he was bitterly disappointed that the one subject he remained convinced exceeded all others in importance, and in which he had done his best work (so he believed), was not more noticed or taken seriously. ${ }^{43}$ Croll spent much of his life in science looking for a chance to return to his metaphysical inquiries and never lost the conviction that even in science, metaphysics should not be excluded from view or made redundant. At the very least, if we wish to produce, to borrow an anthropological term, an 'emic' account of Croll's life and thought we cannot ignore just how much his religious practices, feelings and convictions, and his metaphysical justification of them, informed, animated and motivated his much-admired scientific accomplishments.

\section{References}

Anon. [Croll, J.] 1857. The philosophy of theism. London: Ward \& Co. Anon. 1857. Literature. Greenock Telegraph, 16 December, 1.

Bebbington, D. 2017. The legacy of Jonathan Edwards in Britain. In Bezzant, R. S. (ed) The global Edwards, 1-21. Eugene, Oregon: Wipf and Stock.

Caldwell, J. 1904. Rev. Henry Batchelor. In Clark, H. E. (ed) Memorials of Elgin Place Church, Glasgow: a centenary volume, 1803-1903, 109-16. Glasgow: J. C. Erskine.

Croll, J. 1890. The philosophical basis of evolution. London: Edward Stanford.

Edwards, J. 1957 [1754]. Freedom of the will. In Ramsey P. (ed) Works of Jonathan Edwards, 26 Volumes, Volume 1, New Haven: Yale University Press.

Feser, E. 2013. Between Aristotle and Paley: Aquinas's fifth way. Nova et Vetera 11, 707-49.

Finnegan, D. A. 2012. James Croll: metaphysical geologist. Notes and Records of the Royal Society 66, 69-88.

Gibbs, S. 2010. Closure principles and the laws of conservation and momentum. Dialectica 64, 363-84.

Gribben, C. 2004. Andrew Bonar and the Scottish Presbyterian millennium. In Stunt, T. \& Gribben, C. (eds) Prisoners of hope? Aspects of evangelical millennialism in Britain and Ireland, 1800-1880, 177-202. Carlisle: Paternoster.

Guelzo, C. 2005. Freedom of the will. In Lee, S. H. (ed) Princeton companion to Johnathan Edwards, 115-29. Princeton: Princeton University Press.

Irons, J. C. 1896. Autobiographical sketch of James Croll LL.D., F.R.S., ETC with memoir of his life and work. London: Edward Stanford.

Larsen, T. 2017. Congregationalists. In Larsen, T. \& Ledger-Lomas, M. (eds) The Oxford history of protestant dissenting traditions. Volume III: the nineteenth century, 39-56. Oxford: Oxford University Press.

Livingstone, D. N. 2014. Dealing with Darwin: place, politics and rhetoric in religious engagements with evolution. Baltimore: Johns Hopkins University Press.

McClymond, M. J. 2012. "A German professor dropped into the American forests": British, French and German views of Jonathan Edwards, 1758-1957. In Crisp, O. D. \& Sweeney, D. A. (eds) After Jonathan Edwards: the courses of the new England theology, 208-24. Oxford: Oxford University Press.

McKimmon, E. G. 2019. The secession and united presbyterian church. In Fergusson, D. \& Elliott, M. W. (eds) The history of Scottish theology volume 2: from the early enlightenment to the late Victorian period, 376-89. Oxford: Oxford University Press.

Morison, J. 1858. Critical notices: the Philosophy of Theism. Evangelical Repository 4, 135-40.

Mullin, R. B. 2003. Science, miracles and the prayer-gauge debate. In Lindberg, D. C \& Numbers, R. (eds) When science and Christianity meet, 203-24. Chicago: University of Chicago Press.

\footnotetext{
${ }^{43}$ For example, Croll wrote in 1882 that his as yet unpublished article on 'Evolution by force impossible' was 'by far the best thing I have ever written'. See Irons (1896, p. 368).
} 
Newton, W. 2014. A case of mistaken identity: Aquinas's fifth way and arguments of intelligent design. New Blackfriars $\mathbf{9 5}$, 569-78.

Ryken, P. G. 1999. Thomas Boston as preacher of the fourfold state. Carlisle: Paternoster Press.
Secord, J. 2000. Victorian sensation: the extraordinary publication, reception and secret authorship of vestiges of the natural history of creation. Chicago: University of Chicago Press.

Turner, F. M. 1974. Rainfall, plagues and the Prince of Wales: a chapter in the conflict of religion and science. Journal of British Studies 13, 46-65.

MS received 5 February 2021. Accepted for publication 12 April 2021. First published online 10 May 2021 